Danijela S. Petrović ${ }^{1}$

UNIVERSITY OF BELGRADE, FACULTY OF PHILOSOPHY DEPARTMENT OF PSYCHOLOGY

Miljana S. PaVićević ${ }^{2}$

UNIVERSITY OF PRIŠTINA WITH TEMPORARY HEAD-OFFICE

IN Kosovska Mitrovica, Faculty of Philosophy

DePARTMENT OF PSYCHOLOGY

\title{
RELATIONS BETWEEN ETHNOCENTRISM AND NATIONAL ATTACHMENT
}

ABSTRACT. Belonging and being attached to various social groups such as nationality and ethnicity, can have a significant motivational effect. At the same time, a sense of national attachment can develop into ethnocentrism and become a source of hostility and conflicts among members of different nations, with conflicts in the immediate past contributing to greater manifestations of certain forms of national attachment, and even ethnocentrism. That is why the objectives of this paper were to: (1) determine prominence of ethnocentrism and different forms of national attachment in young people of Serbian nationality in Kosovo and Metohija (345 respondents, average age AS=19,36) (2) investigate what kind of relationship exists between ethnocentrism and national attachment. Instruments used in the research were the Ethnocentrism Scale (Šram, 2010) and Scale of National Attachment Forms (Rot and Havelka, 1973). The results show that of all aspects of ethnocentrism, respondents manifest the greatest degree of national homogenization, distinguished by a strong need for national unity, while the most accentuated form of national attachment is prominent national attachment, character-

dspetrov@f.bg.ac.rs

miljanapavicevic@yahoo.com

The paper is the result of research conducted within project no. 179018 Identification, Measurement and Development of Cognitive and Emotional Competencies Important to a Society Oriented towards European Integrations funded by the Ministry of Education, Science and Technological Development of Republic Serbia.

Рад је примљен 18. августа 2018, а прихваћен за објављивање на састанку Редакције 3ठорника одржаном 3. децембра 2018. 
ized by idealizing one's own nation and emphasizing the feeling of patriotism. Prominent and exclusive forms of national attachment correlate with all the aspects of ethnocentrism which supports the claim that those individuals who are characterized by a high degree of national idealization, which is a feature of both prominent and exclusive national attachment, often demonstrate a certain tendency to react in an ethnocentric way.

KEYWORDS: ethnocentrism; national attachment; adolescents.

\section{INTRODUCTION}

\section{ETHNOCENTRISM}

Ethnocentrism is thoroughly examined concept in psychology and other social sciences, primarily because of its potentially negative influence on intergroup relations (e.g. Adorno, Frenkel-Brunswik, Levinson, \& Sanford, 1950; Hewstone, Rubin \& Willis, 2002; LeVine \& Campbell, 1972). Under certain circumstances, ethnocentrism is considered to contribute to the formation of prejudices, as well as dominance and hostility towards other groups that can grow into conflict and even war (e.g. Bar \& Tal, 1990; Popadić, 2004). Ethnocentrism is also related to negative social phenomena like nationalism, chauvinism, racism, xenophobia, etc. However, as any other key concept, ethnocentrism is determined in different ways which contributes to its conceptual ambiguity. Various entries used when defining ethnocentrism make certain authors (e.g. Tajfel, 1983) see ethnocentrism as an umbrella term which unifies various concepts, while other authors question its usefulness and possibility of reaching to valid conclusions based on vast number of research studies that deal with this diversified concept (e.g. Heaven, Rajab, \& Ray; 1985; Raden, 2003).

The first use of the term ethnocentrism is attributed to Sumner ${ }^{3}$ who uses the term as a technical name for the frame of reference ,in which one's own group is the center of everything, and all others are scaled and rated with reference to it" (Sumner, 1906, p. 13) and which besides its self-centering indicates superiority of an ethnical group as one of the major factors of ethnocentrism: "each group nourishes its own pride and vanity, boasts itself superior, exalts its own divinities, and looks with contempt on outsiders" (ibid.). Superiority as a factor of ethnocentrism is also traceable in the work of Adorno and his asso-

3 For the discussion of who first coined the term ethnocentrism see Bizumic \& Duckitt, 2012 and Buzimic, 2014. 
ciates who define ethnocentrism as an ideology, which is characterized by the fact that members of their own group, their own nation, consider themselves more superior and valuable than the members of other groups, rating those other ethnical and racial groups as less valuable and inferior (Adorno et al., 1950). Beside this, these authors point out that ethnocentrism is characterized by sharp distinction between one's own group and all the others, as well as negative stereotypes and hostile attitudes towards other groups, that is towards anyone classified as alien (ibid.). On the other hand, theories of social identity emphasize the process of developing positive differences in relation to others, and the phenomenon of ethnocentrism is related to the forming of positive social identity based on intergroup comparison. Contrary to the view that hostility and negative attitudes to others are the core feature of ethnocentrism, the theory of social identity sees ethnocentrism primarily as preference for the ingroup over outgroups (Tajfel \& Turner, 1986). Hence, ethnocentrism is most usually considered as extreme affection for one's own group (overemphasised feeling of importance and value of one's own group), and positive discrimination of one's own group members in relation to members of other groups (Brewer, 1999, 2010).

The analysis of different definitions used when studying ethnocentrism carried out by Bizumic \& Duckitt (2012) show that there are three core themes: (1) group self-centeredness (i.e., giving strong importance to one's group), (2) outgroup negativity (i.e., hostility and contempt towards other groups), and (3) mere ingroup positivity (i.e., positive evaluation of one's own group). Additionally, their analysis of the definitions of ethnocentrism suggested six specific facets reflecting the view that one's own group is of central importance: (a) preference for the ingroup over outgroups; (b) the perception of superiority of ingroup over outgroups; (c) the wish to preserve the ethnic purity of one's own group; (d) pursuit of ingroup interest without consideration for outgroups (exploitativeness); (e) the need for group cohesion, and (f) strong devotion to the ingroup.

Most authors agree that ethnocentrism is not a simple one-dimensional phenomenon where one pole signifies affinity to ingroup, and the other pole aversion to outgroup (Bizumic \& Duckitt, 2012), that is, with one extreme representing national exclusiveness, and the other national negation (Šram, 2002 and 2010). For example, the onset of multidimensional view on ethnocentrism can be traced back to Sumner (as cited in Šiber, 1998) who lists, as components of ethnocentrism, feelings of national superiority, existence of strong national 
group cohesion and commitment, and the need for defence of ingroup interests as opposed to outgroup interests. Bizumic and his associates define ethnocentrism as attitudinal construct characterised by the strong feeling of ethnic group self-centeredness and the importance of one's own ethnic group, which is manifested on intergroup and intragroup level. Intergroup expression of ethnocentrism includes four components: preference of members of one's own ethnic group over members of other nations, belief in the superiority of their own ethnic group, the wish for ethnically pure nation and readiness to exploit other nations for their own interests, while intragroup expression of ethnocentrism consists of two components: strong group cohesion and a sentiment of worshiping one's own nation. The base of the intergroup ethnocentrism is the belief that one's ethnic group is more important than others, while intragroup ethnocentrism is based on the belief that the ethnic group is more important than an individual (Bizumic, Duckitt, Popadic, Dru, \& Krauss, 2009). Supposing that ethnocentrism is a multidimensional construct, Šram defines ethnocentrism as a system of relatively related attitudes and beliefs which consists of affective, cognitive, and behavioural components (Šram, 2010). According to this author, ethnocentrism on affective level indicates strong national attachment and readiness for self-sacrifice for national interests; on cognitive level, it indicates perception of a need for national homogenization, presence of national superiority and prejudices; and on behavioural level, it indicates the exclusiveness, mistrust, and bias in interethnic interactions (Šram, 2010).

NATIONAL ATTACHMENT

Guetzkow gave one of the earliest definitions of national attachment in his book Multiple loyalties: theoretical approach to a problem in international organization (Guetzkow 1955, as cited in Turjačanin, 2005) where he defined national loyalty as attachment to national state whether it already exists or there is a growing tendency for it to be formed. Guetzkow (Guetzkow 1955, as cited in Šiber, 1998) was also the first to distinguish several forms of national attachment based on the existence of exclusive loyalty to one's own nation or inclusive of some other ways of loyalty: (1) anationalism - national feelings are harmful or unnecessary; (2) cosmopolitism - attachment to human society, and not a nation; (3) multiple national attachment - internationalism (it is important to belong to the nation, but to belong to the mankind is more important); (4) prominent national attachment (patriotism); (5) 
exclusive national attachment (nationalism, chauvinism, ethnocentrism) (Guetzkow, 1955, as cited in Šiber, 1998). The advantage of Guetzkow's idea is that it presents the feeling of national attachment as reasonable and natural value orientation, and at the same time provides a perspective for overcoming chauvinist nationalism (Rot, 2006).

Following Guetzkow's work and ideas, Rot and Havelka (1973) determine national attachment as a system of interrelated attitudes expressing the relation of an individual to their own nation, national state and territory, national culture, language and history, national treasures and symbols, then to other nations, both those with whom their nation was or is politically or economically related, friendly or hostile as well, and national differentiation as a social phenomenon. One should have positive, neutral, or negative attitude towards each of these objects, which is the basis for distinguishing five ways of national attachment (Rot and Havelka, 1973, p. 12): (1) exclusive national attachment characterised by attachment to one's own nation only with the emphasis on its exceptional values, that is the belief that only belonging to one's own nation is important and significant, while degrading other nations. This form of national attachment corresponds to the notion of ethnocentrism given by Adorno et al. (1950); (2) prominent national attachment which implies strong attachment to one's own nation while accepting the importance of every national attachment and without emphasising the greater value of one's own nation; (3) divided national attachment characterised by the feeling of attachment to one's own nation, but also to wider social groups, above all humanity as a whole, which does not have to exclude attachment to one's own nation; (4) general human attachment characterised by attachment to human community in general and tendency to overcome narrow national interests; (5) non-existence, that is, absence of national attachment characterised by negating of values and importance of national attachment, often considering any national feelings as unnecessary and harmful.

According to Milosavljević (2012), national attachment as a social construct is a polar socio-psychological continuum that ranges from maximum national attachment, so called "national robinsonism", to maximum openness to the world, so called cosmopolitism (understanding that the whole world is considered as a homeland). The author uses the term national robinsonism metaphorically as a proof that life isolated from every other nation is possible. 
One of the most important and most influential sources of national attachment is the common past. Awareness of the common past is formed not only by learning history, but also through national myths. The most common myths are those of common origin, common state, and indestructibility of nation, common interests, and the myth of common enemy (Turjačanin, 2005). National attachment is characterised by strong identification of personal with national and collective. However, national attachment does not entail automatic loss of one's own identity, that is, replacement of personal identity by national identity. Personal identity will be replaced by any collective identity only in those individuals who show certain symptoms of disintegration of personality (Kuzmanović and Šram 1999, as cited in Šram, 2002).

\section{WHEN DOES NATIONAL ATTACHMENT BECOME ETHNOCENTRISM?}

It can be concluded that when determining ethnocentrism most authors agree that it is a comprehensive system of attitudes and opinions characterised by clear distinction between one's own and every other group (especially national or ethnic), where more positive qualities and features are attributed to one's own group and are believed to be more valuable and superior compared to the qualities of other nations. This ethnocentric attitude towards one's own nation represents, at the same time, standard for evaluating other nations and their values. On the other hand, if we adopt the view that strong national group cohesion is a component of ethnocentrism, then the concept of ethnocentrism logically implies the existence of ethnic or national affective attachment, not only perception or the feeling of superiority.

Rot and Havelka (1973) believe that exclusive national attachment corresponds to the notion of ethnocentrism and that exclusive national attachment presents disposition for ethnocentric way of behaviour, especially tendency to emphasize the superiority of one's own nation. Milosavljević (2002) also concludes that national attachment, defined as the belief of an individual that their nation has the greatest value and significance for them, corresponds to what other authors call ethnocentrism, that is, national robinsonism. 


\section{RELATIONS WITH SIMILAR CONSTRUCTS}

Nationalism and patriotism are two special forms of national identification whose meanings are, to a certain extent, similar to the concept of ethnocentrism. In psychological sense, nationalism and patriotism are forms of prominent attachment to one's own country or ethnic group based on the idea of common history, language, territory or culture. The conceptual difference is that patriotism usually signifies attachment to only one's own country, while nationalism involves tendency to favour one's own country in relation to others. Nationalism can also exist in the form of a wish to form one's own national country, while patriotism presupposes its existence (Turjačanin, 2015).

Patriotism is usually defined as a form of identification with a state community. Rejkovski (1997, as cited in Križanec, 2008) distinguish two forms of patriotism: well-intentioned (increasing the welfare and investing in good reputation of one's own country in accordance with the interests of other countries) and hostile patriotism (includes hostile attitudes toward other countries). The difference is often made between blind and constructive patriotism (Schatz, Staub, \&Lavine, 1999; Spry \& Hornsey, 2007; Staub, 1997). Blind patriotism is a form of attachment to one's own country characterized by supporting the country no matter what the consequences of its actions may be to others, while constructive patriotism is devotion and loyalty to the state, but with respect of universal human values. It is established that blind patriotism positively correlates with nationalism, authoritarianism, feelings that the country is vulnerable, and poor political information flow, while constructive patriotism is correlated with gathering of information and empathy (Schatz, Staub, \& Lavine, 1999). If patriotism is determined as extremely positive and uncritical relation to a country and its symbols, then its meaning is closer to the meaning of ethnocentrism. That is, blind patriotism is more like ethnocentrism, unlike constructive patriotism which is closer to the concept of national attachment (Trebješanin, 1999). The concept of blind patriotism (Staub, 1997) comes close to the idea of Bizumic and Duckitt (2012) that it is a devotion facet of ethnocentrism with only difference that the focus of blind patriotism is on one's national group, and the focus of devotion is on one's ethnic group.

Nationalism is also closely related to the notion of ethnocentrism, when it is determined as a wish to support the supremacy and domination of one nation, i.e. state with regard to others (Gellner, 1983) or 
as a widespread system of beliefs with tendency of extreme attachment to one's national group, while at the same time a discriminatory relation to other national groups (Brown, 2010). It can be said that patriotism is closer to intragroup ethnocentrism, while nationalism is closer to intergroup ethnocentrism (Bizumic et al, 2009; Bizumic \& Duckitt, 2012). However, Turjačanin (2015) considers ethnocentrism as a more universal notion than nationalism, because it is often used for all types of groups, while nationalism is used in the state and political context. In areas with various ethnic groups, ethnocentrism can have a political function, spurring nationalism of different types: nationalism of a majority group usually has assimilative and expansive tendencies, while nationalism of a minority group usually includes separatist tendencies (Turjačanin, 2015). It is also determined that there is strong link between major group identity and state identity, which usually does not apply to such extent to minor groups (Staerklé, Sidanius, Green, \& Molina, 2010).

\section{PRESENT STUDY}

National states and ethnic groups are important groups, where the feeling of national and ethnic attachment can be present as the firm system of attitudes with prominent motivational strength. At the same time, the feeling of national attachment can grow into ethnocentrism and become means and source of developing hostility and conflicts among members of different nations, with conflicts in the immediate past contributing to greater manifestation of certain forms of national attachment, even ethnocentrism. Despite their unquestionable significance, relations of ethnocentrism and national attachment in our environment and region were not given due attention. The only exception are some studies that show connection between exclusive national attachment and ethnocentrism (e.g., Đorđević, 1995, as cited in Puhalo, 2013; Milošević-Đorđević, 2005, Šram, 2002).

\section{METHOD}

\section{SUBJECT AND OBJECTIVES OF THE RESEARCH}

This paper investigates the relationship between ethnocentrism and a form of national attachment in adolescents. The main objective of 
the research was to investigate whether there is any connection between ethnocentrism and national attachment. In addition, the objective of the research was to determine the degree of expression and distribution of these variables.

VARIABLES

Ethnocentrism is determined as a system of attitudes expressing the superiority of one's social group and its values compared to others, and it is derived from group-centrism, that is the need of an individual to belong and be identified (Šiber, 1998), while national attachment is defined as a system of interconnected attitudes or feelings of belonging to a national group, acquired in the process of socialization, through which language, tradition, and culture of a national group are received; consequently, an individual identifies themselves with group values and interests, as well as with a group as a whole (Rot and Havelka, 1973; Trebješanin, 2004).

INSTRUMENTS

Ethnocentrism scale (Ethno-3) shows different aspects of ethnocentric attitudes and potential behaviour in interethnic social transactions (Šram, 2010). It consists of 23 items which the respondents rate on the five-point Likert scale. Theoretical range of the results varies from 23 to 115 points. Four factors are distinguished in this scale and the authors threat them as subscales": national affective attachment and self-sacrifice contains 8 items and shows the presence of strong national identification and readiness to self-sacrifice (e.g. "I am ready to die for the dignity and interests of my nation"); national exclusiveness and prejudices contains 7 items and defines international distrust, isolation in social transactions, and prejudices (e.g. "I can hardly be a true friend with a person who is not my nationality"); national superiority and bias contains 5 items and shows the perception of general, moral, and intellectual national superiority and a favouritism in formal social interactions (e.g. "My nation is superior when compared to many other nations"); national homogenization which contains 3 items and shows the need for national unity (e.g. "All members of my nation must hold tight together if we do not want to see national disaster").

4 The use of subscale allows a more subtle analysis of a relation between ethnocentrism and other constructs 
Šram (2010) cites reliability of the scale of $\alpha=.91$, while reliability of the scale in the present study was $\alpha=.89$ (and for subscales were from $\alpha=.62$ to $\alpha=.83$ ).

Scale of national attachment forms (Rot and Havelka, 1973) is a seven-point Likert scale which consists of 35 questions divided into 5 subscales (6 questions on each subscale). Theoretical range of results on each subscale goes from 6 to 42 points. Subscales are: exclusive national attachment (shows the significance of belonging to one's own nation and disdain of other nations, e.g. "All the members of my nation should always and in every way appreciate more their own nation than any other"); prominent national attachment (idealizing of one's own nation, emphasising the feeling of patriotism and giving importance to national attachment in members of one's own and other nations, e.g. "the feeling of attachment to one's own nation in members of any nation is one of the most wonderful feelings that a person can have"); divided national attachment (concurrent loyalty to one's own nation and to international cooperation and coexistence, e.g. "I feel as much a member of my own nation, as a member of general human community"); attachment to human community (emphasises the attachment to mankind and the necessity of overcoming national attachment and narrow national interests for the sake of human progress and the progress of the world as a whole, e.g. ("Humanity presents the only true human community, hence every division into nations is either harmful or meaningless"); non-existence of national attachment (entails the absence of attachment to any nation; e.g. "I would feel as good in any other country as in this one right now, if I had good living conditions there"). The reliability of the subscales in our research was between $\alpha=.58$ and $\alpha=.73$.

SAMPLE

Sample consisted of young people from Kosovo and Metohija of Serbian nationality, total of 345 (47\% boys and 53\% girls; 63\% secondary school students (final year) and $37 \%$ university students), average age $\mathrm{AS}=19.36 ; \mathrm{SD}=1.944$. All respondents were asked for consent to participate in the research, which they granted. All the respondents are of Serbian nationality, and only $5.2 \%$ of their parents do not belong to the same nation. More than a half of the respondents from the sample (66.1\%) declare to have friends from other cultures. $25.5 \%$ of respondents have never travelled abroad. $20 \%$ of the respondents cannot communicate in any other language (other than Serbian), although 
$40 \%$ of the respondents declare to listen to shows and music in some other language.

\section{RESULTS}

\section{PROMINENCE OF ETHNOCENTRISM}

Table 1 shows average values on Ethnocentrism scale (Ethno-3) as a whole as well as on each of it's subscales. The range of results on Ethno- 3 scale is between 26 to 114 points, while average result is $M=71.78$, with scattering of results of $\mathrm{SD}=16.20$.

\begin{tabular}{|c|c|c|c|c|c|c|}
\hline & $\mathrm{N}$ & Min. & MaX. & AS & SD & $\begin{array}{l}\text { CORRECTED } \\
\text { scores }^{\mathrm{a}}\end{array}$ \\
\hline $\begin{array}{l}\text { NATIONAL AFFECTIVE ATTACHMENT AND } \\
\text { ETHNOCENTRISM }\end{array}$ & 345 & 8 & 40 & 28.06 & 6.79 & 3.51 \\
\hline NATIONAL EXCLUSIVENESS AND PREJUDICES & 345 & 7 & 35 & 18.33 & 6.18 & 2.62 \\
\hline NATIONAL SUPERIORITY AND BIAS & 345 & 5 & 25 & 14.05 & 4.56 & 2.81 \\
\hline NATIONAL HOMOGENIZATION & 345 & 3 & 15 & 11.33 & 2.52 & 3.78 \\
\hline TOTAL SCORE & 345 & 26 & 114 & 71.78 & 16.20 & 3.12 \\
\hline
\end{tabular}

TABLE 1: DESCRIPTIVE INDICATORS OF PROMINENCE OF CERTAIN ASPECTS OF ETHNOCENTRISM

a Since subscales contain different number of items, a correction was done so that average value was divided by number of items on a subscale in order to compare the prominence of aspects of ethnocentrism.

According to average values of ethnocentrism, our respondents manifest more ethnocentrism than other young people in the region. In the relevant research, which Šarm (2010) realized on the sample of Croatian students from the University of Zagreb, it was established that the average score on Ethno-3 scale was $\mathrm{M}=50.4$ ( $\mathrm{SD}=14.42)$.

Regarding expressing different aspects of ethnocentrism, the results show that the most prominent aspect in young people from Kosovo and Metohija was national homogenization $(M=3.78)$, then national affective attachment and self-sacrifice $(M=3.51)$, while less prominent are national superiority and bias $(\mathrm{M}=2.81)$, and national exclusiveness and prejudices $(M=2.62)$. The analysis of significance of 
differences (t-test of paired samples) shows that all determined differences in expressing certain aspects of ethnocentrism are statistically relevant on the level 0.001 (see Pavićević \& Petrović, 2016).

The most prominent aspect in our sample was national homogenization, while in Šram's research (2010), the dominant aspect of ethnocentrism was national affective attachment and self-sacrifice, which means that different aspects of ethnocentrism in these two studies, contribute to the final score on the scale of ethnocentrism.

Based on the distribution of results shown in Figure 1, it is obvious that they correspond to the normal distribution, which is confirmed also by measures of asymmetry (skewness $=-.054$; Std. Error of Skewness $=.131$ ) and flattening of Gaussian curve (Kurtosis=.024; Std. Error of Kurtosis=.262).

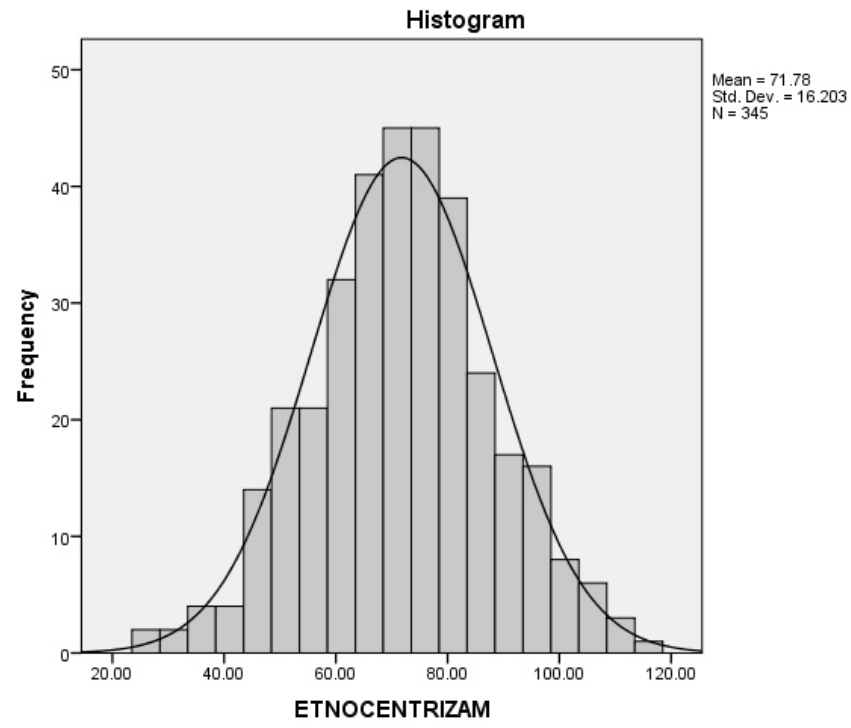

FIGURE 1: RESULTS OF THE DISTRIBUTION OF THE ETHNOCENTRISM SCALE (ETNO-3)

According to the score on the scale Ethno-3, respondents are classified into 5 categories that reflect different levels of the presence of ethnocentrism (see Table 2): low (the results in the range of minimum score to -1.5 of standard deviation below arithmetic mean), below-average (the results in the range from -1.5 to -0.5 of standard deviation below arithmetic mean), average (the results in the range from -0.5 to +0.5 of standard deviation from arithmetic mean), above-average (results in the range from 0.5 to 1.5 above arithmetic mean), and extreme- 
ly high level of ethnocentrism (results in the range of 1.5 of standard deviations above arithmetic mean to the maximum score). The results show that every fourth respondent or $26.7 \%$ expresses above-average level of ethnocentrism, while high level of ethnocentrism is registered in $2.3 \%$ of respondents (because of the normality of distribution of the results, the same percentage of respondents is registered as expressing below average level and extremely low level of ethnocentrism).

\begin{tabular}{|l|l|l|l|l|}
\hline & RANGE OF Z-VALUE FROM ARITHMETIC MEAN & $\begin{array}{l}\text { RESULT } \\
\text { (POINTS) }\end{array}$ & F \\
\hline EXTREMELY LOW & Minimum to -1.50 & $26-38$ & 8 & 2.3 \\
\hline BELOW AVERAGE & -1.50 to -0.50 & $39-63$ & 92 & 26.7 \\
\hline AVERAGE & -0.50 to 0.50 & $64-80$ & 145 & 42 \\
\hline ABOVE AVERAGE & 0.50 to 1.50 & $81-105$ & 92 & 26.7 \\
\hline EXTREMELY HIGH & 1.50 to maximum & $106-114$ & 8 & 2.3 \\
\hline
\end{tabular}

TABLE 2: LEVEL OF PRESENCE OF ETHNOCENTRISM

\section{PROMINENCE OF NATIONAL ATTACHMENT}

The results given in the Table 3 show that the young people in Kosovo and Metohija express, most of all, prominent $(\mathrm{M}=29.50)$ and divided national attachment $(M=28.75)$. The difference in expressing these two forms of national attachment is significant at level .05 (see Table 4). The results show that exclusive national attachment $(M=26.06)$ and attachment to human community are equally present $(M=26.26)$, while all the other differences in expressing certain forms of national attachment are significant at level 0.01 (see Table 4). Indifferent attitude toward expressing national attachment is present to the least extent $(\mathrm{M}=24.25)$, compared to other forms of national attachment.

\begin{tabular}{|l|l|l|l|l|l|}
\hline & N & MIN. & MAX. & M & SD \\
\hline $\begin{array}{l}\text { EXCLUSIVE NATIONAL } \\
\text { ATTACHMENT }\end{array}$ & 345 & 6 & 42 & 26.06 & 7.52 \\
\hline $\begin{array}{l}\text { PROMINENT NATIONAL } \\
\text { ATTACHMENT }\end{array}$ & 345 & 9 & 42 & 29.50 & 6.93 \\
\hline
\end{tabular}

TABLE 3: DESCRIPTIVE INDICATORS OF PROMINENCE OF CERTAIN FORMS OF NATIONAL ATTACHMENT 


\begin{tabular}{|l|l|l|l|l|l|}
\hline DIVIDED NATIONAL ATTACHMENT & 345 & 12 & 42 & 28.75 & 6.36 \\
\hline $\begin{array}{l}\text { ATTACHMENT TO HUMAN } \\
\text { COMMUNITY }\end{array}$ & 345 & 6 & 42 & 26.26 & 6.74 \\
\hline $\begin{array}{l}\text { NON-EXISTENCE OF NATIONAL } \\
\text { ATTACHMENT }\end{array}$ & 345 & 6 & 42 & 24.25 & 6.22 \\
\hline
\end{tabular}

TABLE 3: DESCRIPTIVE INDICATORS OF PROMINENCE OF CERTAIN FORMS OF NATIONAL ATTACHMENT

\begin{tabular}{|c|c|c|c|c|c|c|}
\hline & M & $\begin{array}{l}\text { DIFFERENCE } \\
\mathrm{M}\end{array}$ & SD & $\mathrm{T}$ & $\mathrm{DF}$ & P \\
\hline PAIR 1: EXCLUSIVE/PROMINENT & \begin{tabular}{|l|}
26.06 \\
29.50
\end{tabular} & -3.45 & 6.22 & -10.28 & 344 & .000 \\
\hline PAIR 2: EXCLUSIVE/DIVIDED & $\begin{array}{l}26.06 \\
28.75\end{array}$ & -2.69 & 8.39 & $\mid-5.98$ & 344 & .000 \\
\hline PAIR 3: EXCLUSIVE/HUMAN COMMUNITY & $\begin{array}{l}26.06 \\
26.26\end{array}$ & -.20 & 9.34 & -.398 & 344 & .691 \\
\hline PAIR 4: EXCLUSIVE/NON-EXISTANCE & $\begin{array}{l}26.06 \\
24.25\end{array}$ & 1.81 & 8.99 & 3.74 & 344 & .000 \\
\hline PAIR 5: PROMINENT/DIVIDED & $\begin{array}{l}29.50 \\
28.75\end{array}$ & .75 & 6.98 & 1.99 & 344 & .047 \\
\hline PAIR 6: PROMINENT/HUMAN COMMUNITY & $\begin{array}{l}29.50 \\
26.26\end{array}$ & 3.25 & 8.81 & 6.84 & 344 & .000 \\
\hline PAIR 7: PROMINENT/NON-EXISTENCE & $\begin{array}{l}29.50 \\
24.25\end{array}$ & 5.26 & 9.38 & 10.41 & 344 & .000 \\
\hline PAIR 8: DIVIDED/HUMAN COMMUNITY & $\begin{array}{l}28.75 \\
26.26\end{array}$ & 2.49 & 6.03 & 7.69 & 344 & .000 \\
\hline PAIR 9: DIVIDED/NON-EXISTENCE & $\begin{array}{l}28.75 \\
24.25\end{array}$ & 4.51 & 7.47 & 11.20 & 344 & .000 \\
\hline PAIR 10: UNIVERSALLY HUMAN/NON-EXISTENCE & $\begin{array}{l}26.26 \\
24.25\end{array}$ & 2.01 & 5.97 & 6.26 & 344 & .000 \\
\hline
\end{tabular}

TABLE 4: THE RESULTS OF PAIRED SAMPLES T-TEST

Regarding forms of national attachment, the results were different from original results of Rot and Havelka (1973). Namely, our research shows greater values for exclusive national attachment, while divided and universally human are lower compared to the results of Rot and Havelka's research. On the other hand, the results of our research agree with the results of one more recent research, done by Grahek 
(2008), where the increase of exclusive national attachment was also registered.

\section{RELATIONS OF ETHNOCENTRISM AND FORMS OF NATIONAL ATTACHMENT}

According to data given in the Table 5, we can see that correlations of high and mid intensity ${ }^{5}$ prevail between exclusive and prominent national attachment on one side, and all the aspects of ethnocentrism, on the other, which was expected because exclusive national attachment is most often equated with ethnocentrism (psychological content of exclusive national attachment is expressed as nationalism, ethnocentrism, and chauvinism) and it is considered that exclusive national attachment presents a disposition for ethnocentric behaviour and tendency to emphasise the superiority of one's own nation.

\begin{tabular}{|l|l|l|l|l|l|}
\hline & $\begin{array}{l}\text { EXCLUSIVE } \\
\text { NATIONAL } \\
\text { ATTACHMENT }\end{array}$ & $\begin{array}{l}\text { PROMINENT } \\
\text { NATIONAL } \\
\text { ATTACHMENT }\end{array}$ & $\begin{array}{l}\text { DIVIDED } \\
\text { NATIONAL } \\
\text { ATTACHMENT }\end{array}$ & $\begin{array}{l}\text { ATTACHMENT TO } \\
\text { HUMAN } \\
\text { COMMUNITY }\end{array}$ & $\begin{array}{l}\text { NON-EXISTENCE } \\
\text { OF NATIONAL } \\
\text { ATTACHMENT }\end{array}$ \\
\hline $\begin{array}{l}\text { NATIONAL } \\
\text { AFFECTIVE } \\
\text { ATTACHMENT AND } \\
\text { SELF-SACRIFICE }\end{array}$ & $.528^{* *}$ & $.569^{* *}$ & $.175^{* *}$ & .048 & -.043 \\
\hline $\begin{array}{l}\text { NATIONAL } \\
\text { EXCLUSIVENESS } \\
\text { AND PREJUDICES }\end{array}$ & $.498^{* *}$ & $.267^{* *}$ & $-.107^{*}$ & -.060 & .082 \\
\hline $\begin{array}{l}\text { NATIONAL } \\
\text { SUPERIORITY AND } \\
\text { BIAS }\end{array}$ & $.551^{* *}$ & $.328^{* *}$ & -.043 & .052 & .069 \\
\hline $\begin{array}{l}\text { NATIONAL } \\
\text { HUMANISATION }\end{array}$ & $.353^{* *}$ & $.474^{* *}$ & $.149^{* *}$ & -.023 & -.066 \\
\hline * p<0.05; & $*$ p<0.01 & & \\
\hline
\end{tabular}

TABLE 5: CORRELATION OF ETHNOCENTRISM AND NATIONAL ATTACHMENT FORMS

Moreover, Rot and Havelka (1973) claim that in individuals characterised by high level of national idealization (which is a feature of both exclusive and prominent national attachment) there is often a certain tendency to ethnocentric reacting. The strongest correlation

5 According to Cohen, (1988, as cited in Pallant, 2009) correlations of high intensity are in the range from $r=.0 .50$ to $r=1$, mid intensity in the range from $r=0.30$ to $r=0.49$, while those in the range of $r=0.10$ to $r=0.29$ are considered to be low. 
$(r=0.57)$ determined between national attachment (which signals idealizing of one's own nation, emphasising the feeling of patriotism, and giving significance to national attachment), aspects of ethnocentrism and self-sacrifice, confirms this claim and also suggests the presence of strong national identification. All these correlations are significant at 0.01 , while the correlation between divided national attachment and national exclusiveness and prejudices is significant at 0.05. Negative prefix of correlation shows that decreased national exclusiveness and prejudices towards other nations brings higher level of divided national attachment, which is greater respect for other nations and greater equality among nations.

\section{DISCUSSION}

Interethnic conflicts can escalate into ethnic homogenization (Vasović, 1999), hence our finding that respondents in our research manifest greater national homogenization, which is the need for national unity, is not surprising. Also, the areas affected by war and economic crisis are characterised by turning to traditional identities, which at that moment offer reliable and verified orientations in the sphere of values and symbols of identification (Vasović and Gligorijević, 2011). Under these circumstances, the collectivistic orientation, homogenization, giving importance to national group as opposed to other groups and start to become more significant. The feeling of vulnerability of young Serbs in Kosovo and Metohija, whether it is real or perceived, makes their distrust in other nations stronger, as well as their identification with their own ethnic group.

Regarding national attachment, persons characterised by prominent national attachment claim that national feeling is the most wonderful feeling that enriches a person, and they accept the destiny of their nation as their own destiny (Rot and Havelka, 1973). During interethnic conflicts and after, a national group becomes a dominant form of identification (Vasović and Gligorijević, 2011) which is the exact case with young people in Kosovo and Metohija, who manifest prominent national attachment as their dominant form of national orientation. One can say that national self-consciousness is increased under the influence of interethnic conflicts and economic crisis, hence it is clear why nation is perceived as a primary community.

If we bear in mind the fact that our respondents live in the region of Kosovo and Metohija, with constant fear for the safety of their fam- 
ilies and themselves, it is understandable that these circumstances boost the need to belong to a group and the need for emotional support (Horovitz, 2000, as cited in Milošević Đorđević, 2003) and also the feeling of national attachment, which can result in ethnocentrism. However, according to the results of this research, exclusive national attachment, closely related to ethnocentrism, is expressed less than all other attachments in young people from Kosovo and Metohija.

The most prominent aspects of ethnocentrism in our sample are national homogenization and national affective attachment and self-sacrifice - two aspects of intra-group ethnocentrism. According to Šram (2010), intra-group ethnocentrism presents the type of national cohesion that can be manifested in the form of (1) worshiping of one's own nation, which entails the readiness of an individual to sacrifice their own interests and life for the interests and benefit of their nation; (2) the need for national unity, which entails the perception of nation as extended family. This result can be explained by the feeling of "minority" status that Serbs have in Kosovo and Metohija. According to the theory of social identification (Tajfel and Turner, 1986), the minority group in contact with majority group can develop low self-esteem that can lead to the creation of one of three levels of self-defence: (1) rejection of the current social identity and transit to a majority group, (2) the development of pride inside the group as a consequence of comparing themselves with other minorities, and finally (3) neglecting the aspects that make the group seem inferior and creating their own rules and norms. Regarding the young people in Kosovo and Metohija, we believe that they have developed pride and increased loyalty to the Serbian ethnic group.

Zvonarević (1976, as cited in Turjačanin, 2005) cites possible psychological factors which contribute to the creation and maintenance of what is nationally relevant to an individual. Firstly, an individual can identify with a nation, that is, with something big, valuable, and eternal, which gives significant support to an alienated and insecure person. That identification also secures his orientation in potentially unclear situations, which saves him the "mental effort' when in psychological conflict. Additionally, being a part of great and powerful nations secures real protection and advantage in some critical moments. Secondly, in the process of socialization, loyalty and love for one's own nation has a significant place in family, school, and other social institutions.

The fact that there was more exclusive national attachment found in our research than in the research of Rot and Havelka (1973) can be 
explained by the strengthening of nationalistic tendencies which followed after the fall of communism and disintegration of SFRY, which offered strong state power, strong state, and most often a remarkable leader (Biro 2006). Exclusive national attachment entails idealistic relation to one's own nation and state. Furthermore, it is a form of national attachment where many features of authoritarian character, such as aggresivnes, destructiveness and various stereotypes, can be expressed trough hatred of other nations. On the other hand, decreased level of divided national attachment compared to the research of Rot and Havelka (1973) can be explained by the fact that in the 1990's Serbia was isolated from the rest of the world, which contributed to seeing other nations as hostile (Biro 2006). Under these circumstances, people are expected to reject the cooperation between nations and to turn to their own.

CONCLUSION Based on the results of this research, it can be concluded that ethnocentrism and national attachment are related to a certain extent, with certain similarities and differences. Our research revealed high positive correlations between exclusive and prominent national attachment with all the aspects of ethnocentrism which is in line with the view of Rot and Havelka (1973) that exclusive national attachment is equal to ethnocentrism, i.e. that psychological content of exclusive national attachment is expressed as ethnocentrism. On the other hand, the fact that prominent national attachment is related to all aspects of ethnocentrism is in accordance with the results of Popadić's research (2004), who discovered that emphasising the ethnicity encourages the development of ethnocentrism. Unlike him, Šram (2002) stated that certain entities like national isolation and national attachment are integrated dimensions of ethnocentrism. We consider that the view of Dekker and Malkov (1994, as cited in Šiber 1998) on the relation between ethnocentrism and national attachment is more fruitful, since they treat relation to the national as a hierarchical structure which includes both national attachment and ethnocentrism.

The results can be interpreted in relation to the fact that our respondents live in the areas where their immediate neighbours are Albanians. Great number of research (Biro et al., 2001; Biro et al., 2002; as cited in Mihić and Mihić, 2003) show that the main stereotypes are, above all, against Albanians, then Roma, Croats, Slovenians, and others, even without any direct contact with them. The average age of respondents in our research should also be considered AS=19.36, which indicates the fact that they did not have much direct contact with the 
neighbouring nations, hence their attitudes and relations to nation are most probably transferred form of their parents' behaviour.

The limitation of the research results from the sample. This research involves adolescents from Kosovo and Metohija who live in a specific political atmosphere (limited freedom of movement, violated human rights), which could have some effect on the results. Therefore, in order to examine the relation of ethnocentrism and national attachment more closely, this research should be realised on a more representative sample.

REFERENCES Adorno I. W., Frenkel-Brunswlk E., Levinson D. J. \& Sanford R N. (1950). The authoritarian personality. Oxford, England: Harpers.

Bar \& Tal, D. (1990). Causes and consequences of delegitimization: Models of conflict and ethnocentrism. Journal of Social Issues, 46 (1), 65-81.

Biro, M. (2006). Homo Postommunisticus. Beograd: Biblioteka XX vek.

Bizumic, B. (2014). Who coined the concept of ethnocentrism? A brief report. Journal of Social and Political Psychology, 2 (1), 3-10.

Bizumic, B., \& Duckitt, J. (2012). What is and is not ethnocentrism? A conceptual analysis and political implications. Political Psychology, 33 (6), 887-909.

Bizumic, B., Duckitt, J., Popadic, D., Dru, V., \& Krauss, S. (2009). A cross-cultural investigation into a reconceptualization of ethnocentrism. European Journal of Social Psychology, 39, 871-899.

Brewer, M. B. (1999). The psychology of prejudice: Ingroup love and outgroup hate?. Journal of social issues, 55 (3), 429-444.

Brewer, M. B. (2010). Intergroup relations. Oxford: Oxford University Press.

Gellner, E. (1983). Nations and Nationalism. Ithaca, New York: Cornell University Press.

Grahek, I. (2008). Promene u oblicima nacionalne vezanosti i autoritarnost kod srednjoškolaca u poslednjih 35 godina. Petničke sveske 64, 417-431.

Heaven, P.C. L., Rajab, D \& Ray, J. (1985). Patriotism, Racism, and the Disutility of the Ethnocentrism Concept. The Journal of Social Psychology 125 (2), 181-185.

Hewstone, M., Rubin, M., \& Wilis, H. (2002). Intergroup bias. Annual Review of Psychology, 53, 575-604.

Križanec, T. (2008). Povezanost nacionalnog identiteta i alocentrizma / idiocentrizma. (Neobjavljen diplomski rad). Sveučilište u Zagrebu, Filozofski fakultet, Odsjek za psihologiju.

LeVine, R. A., \& Campbell, D. T. (1972). Ethnocentrism. New York: John Wiley. 
Mihić, V., Mihić, I. (2003). Poznajem, prihvatam, poštujem - istraživanje etničke distance kod dece i njihovih roditelja. Psihologija, Vol. 36 (2), 167-182.

Milosavljević, B. (2002). Porodica i mladi - socijalno-psihološka istraživanja. Banja Luka: Filozofski fakultet.

Milošević Đorđević, J. (2003). Jedan pokušaj klasifikacije teorijskih razmatranja nacionalnog identiteta. Psihologija, 1-2, 125-137.

Milošević Đorđević, J. (2005): Nacionalni identitet: psihološka analiza naučnih i laičkih svatanja (doktorska disetacija). Beograd, Filozofski fakultet Baograd.

Pallant, J. (2009). SPSS: priručnik za preživljavanje - postupni vodič kroz analizu podataka pomoću SPSS-a za Windows (verzija 15). Beograd: Mikro knjiga.

Pavićević, M., Petrović, D. (2016). Povezanost vaspitnih stavova roditelja i etnocentrizma adolescenata. Zbornik radova Filozofskog fakulteta Univerziteta $u$ Prištini, XLVI (1), 375-397.

Popadić, D. (2004). Koreni etnocentrizma. U: S. Mihailović (ur.), Mladi zagubljeni u tranziciji (str. 95-118). Beograd: Centar za proučavanje alternative.

Puhalo, S. (2013). Kako opažamo druge etničke grupe i njihove članove. Socijalna percepcija i etnička pripadnost kod srednjoškolaca u Bosni i Hercegovini. Sarajevo: Friedrich Ebert Stiftung.

Raden, D. (2003). Ingroup Bias, Classic Ethnocentrism, and Non-Ethnocentrism Among American Whites. Political Psychology, 24 (4), 803-828.

Rot, N. (2006). Osnovi socijalne psihologije. Beograd: Zavod za udžbenike i nastavna sredstva.

Rot, N., Havelka, N. (1973). Nacionalna vezanost $i$ vrednosti kod srednjoškolske omladine. Beograd: Institut za psihologiju i Institut društvenih nauka.

Schatz, R. T., Staub, E., \& Lavine, H. (1999). On the varieties of national attachment: Blind versus constructive patriotism. Political Psychology, 20 (1), 151174.

Spry, C., \& Hornsey, M. (2007). The influence of blind and constructive patriotism on attitudes toward multiculturalism and immigration. Australian Journal of Psychology, 59(3), 151-158.

Staerklé, C., Sidanius, J., Green, E.G.T., \& Molina, L. (2010). Ethnic Minority-Majority Asymmetry in National Attitudes around the World: A Multilevel Analysis. Political Psychology, 31 (4), 491 - 519.

Staub, E. (1997). Blind versus constructive patriotism: Moving from embeddedness in the group to critical loyalty and action. In D. Bar-Tal \& E. Staub (Eds.), Patriotism: In the lives of individual and nations (pp. 213-228). Chicago: Nelson-Hall.

Sumner, W. G. (1906). Folkways. Boston: Ginn and Company. 
Šiber, I. (1998). Osnove političke psihologije. Zagreb: Politička kultura.

Šram, Z. (2008). Etnocentrizam, autoritarne tendencije i religioznost: relacije na uzorku zagrebačkih studenata. Migracijske i etničketeme, 24 (1-2), 49-66.

Šram, Z. (2010). Etnocentrizam, percepcija prijetnje i hrvatski nacionalni identitet. Migracijske i etničketeme, 26 (2), 113-142.

Šram. Z. (2002). Dimenzije etnocentrizma i nacionalna pripadnost. Društvena istraživanja, 57 (1), 1-22.

Tajfel, H., \& Turner, J. C. (1986). The Social Identity Theory of Intergroup Behavior. Psychology of Intergroup Relations, 5, 7-24.

Trebješanin, Ž. (2004). Rečnik psihologije. Beograd: Stubovi kulture.

Turjačanin, V. (2005). Predikcija nacionalne vezanosti i otvorenosti. U: V. Turjačanin i Đ. Čekrlija (ur.), Ličnost $i$ društvo II, Etnički, državni i evropski identitet. Banja Luka: Fondacija Friedrich Ebert Stiftung, 102-112.

Turjačanin, V. (2015). Socijalna psihologija etničkog identiteta. Banja Luka: Filozofski fakultet.

Vasović, M. (1999). Etnička mržnja u Srba kao propagandni mit. Sociološki pregled, vol. XXXIII, 1-2, 21-33.

Vasović, M., Gligorijević, M. (2011). Demokratske promene u Srbiji i proces deetnifikacije društvene svesti. Godišnjak Fakulteta političkih nauka, 2011, 5(5), 103-118.

ДАНИЈЕЛА С. ПЕТРОВИЋ

УНИВЕРЗИТЕТ У БЕОГРАДУ, ФИЛОЗОФСКИ ФАКУЛТЕТ

ОДЕљЕњЕ ЗА ПСИХОЛОГИЈУ

МИЉАНА С. ПАВИКЕВИЋ

УНИВЕРЗИТЕТ У ПРИШТИНИ С ПРИВРЕМЕНИМ СЕДИШТЕМ

У КОСОВСКОЈ МИТРОВИЦИ, ФИЛОЗОФСКИ ФАКУЛТЕТ

КАТЕДРА ЗА ПСИХОЛОГИЈУ

РЕЗИМЕ

РЕЛАЦИЈЕ ИЗМЕЂУ ЕТНОЦЕНТРИЗМА И НАЦИОНАЛНЕ ВЕЗАНОСТИ

Припадност и везаност за различите друштвене групе, као што су национална држава и етничка група може да има изражену мотивациону снагу. Истовремено, осећај националне везаности може да прерасте у етноцентризам и да постане извор непријатељства и сукоба међу припадницима различитих нација, као што и конфликти у непосредној прошлости могу да допринесу већем испољавању појединих облика националне везаности, па и етноцентризма. $3 \delta$ о тога ово истраживање мало за циљ да: 
(1) утврди израженост етноцентризма и различитих форми националне везаности код младих српске националности на Косову и Метохији (345 испитаника, просечне старости $\mathrm{AC}=19,36)$; (2) испитамо каква врста релација постоји између етноцентризма и националне везаности. У истраживању су коришћене Скала за процену етноцентризма (Шрам, 2010) и Скала облика националне везаности (Рот и Хавелка, 1973). Резултати показују да од аспеката етноцентризма испитаници испољавају највиши степен националне хомогенизације коју одликује снажна потреба за националним јединством, док је најизраженији облик националне везаности истакнута национална везаност за коју је карактеристично идеализовање сопствене нације и истицање осећања патриотизма. Истакнута и искључива национална везаност су повезане са свим аспектима етноцентризма што говори у прилог тези да особе које карактерише висок ниво националне идеализације, што је одлика искључиве и истакнуте националне везаности, често испољавају и извесну тенденцију ка етноцентричком начину реаговања.

КљУчнЕ РЕчи: етноцентризам; национална везаност; адолесценти. ${ }^{6}$

Овај чланак је објављен и дистрибуира се под лиценцом Creative Commons Ауторство-Некомерцијално Међународна 4.0 (СС BY-NC 4.0 | https://creativecommons.org/licenses/by-nc/4.0/). This paper is published and distributed under the terms and conditions of the Creative Commons Attribution-NonCommercial International 4.0 licence (CC BY-NC 4.0 | https://creativecommons.org/licenses/by-nc/4.0/).

6 Рад је урађен у оквиру пројекта $\delta$ р. 179018 Идентификација, мерење и развој когнитивних и емоционалних компетенција важних друштву оријентисаном на европске интеграције који финансира Министарство просвете, науке и технолошког развоја Републике Србије. 